\title{
39
}

\section{UNITED KINGDOM The developing relationship between science and society}

\author{
Melanie Smallman, Simon J. Lock \\ and Steve Miller
}

The 1950s British Prime Minister Harold Macmillan is reported to have replied to a journalist's question as to what was likely to blow his government off course with the words 'events, dear boy, events'.

The development of science communication in the UK from the mid-1980s onwards is one of the best-documented stories in this field, punctuated by a series of reports from both the scientific community and the government itself - and by a number of 'Macmillian events' that blew science's relationship with the wider world hither and thither. Here we offer a series of episodes that changed how we think about the relationship between science and society. We describe these largely chronologically and imply that they heralded new eras of science communication. This does not mean, however, that previous approaches simply disappeared: many old ideas were buried momentarily or continued as an undercurrent, less visible but ready to resurface as and when conditions allowed and required them to do so.

\section{The advent of the 'modern' era: From 'mad cows' to the 'crisis' in science communication (1985-97)}

During the 1980s, the Conservative government of Margaret Thatcher adopted a policy for scientific research that prioritised near-market, applied projects over those of a more fundamental, 'pure science' nature, as part of its efforts to harness science as a driver of economic growth (Agar, 2011; Guise, 
2014). The scientific community was concerned and a feeling grew that this (as they saw it) misguided and short-termist approach was due to a failure of politicians and the wider public to understand science (understood widely to include science, technology, engineering and medicine (STEM)). More 'public understanding of science' (PUS) was needed.

In 1985, the Royal Society (RS, founded in 1660), the UK's premier scientific society, published a report on 'The Public Understanding of Science' (Royal Society, 1985), referred to as the Bodmer Report ${ }^{1}$ after Sir Walter Bodmer, the chair of the committee that drew it up. This was pivotal: amongst other things, it stated that scientists should consider it their duty to communicate to their fellow citizens about their work and its importance, galvanising and authorising researchers to communicate with the 'general public'.

Bodmer resulted in the establishment of the Committee on Public Understanding of Science (COPUS), with representatives from the RS, the British Association for the Advancement of Science (founded in 1831, and now the British Science Association (BSA)), and the Royal Institution (RI). COPUS organised funding schemes for PUS activities, and handed out prizes for initiatives, individuals and science popularisation books — of which there followed quite a boom, led by Stephen Hawking's 1988 Brief History of Time. A national science week was established in 1994; typical of the UK it managed not to coincide with its continental European counterpart.

In 1989, John Durant (the first UK Professor of Public Understanding of Science at Imperial College), Geoffrey Evans and Geoffrey Thomas published the first major survey of public understanding of science in the UK. They found high levels of interest, but that only some 14 per cent of British citizens could be called 'scientifically literate' (a term imported from the United States) according to tests of knowledge of scientific terms and processes. They concluded: 'If modern science is our greatest cultural achievement, then it is one of which most members of our culture are largely ignorant' (Durant, Evans and Thomas, 1989, p. 13). To the scientific institutions involved in PUS activities this confirmed a deficit in the public understanding of science, and the battle was on to fix that deficit before it was filled by charlatans and soothsayers (see Richard Dawkins' 1996 Richard Dimbleby Lecture on BBC TV, for example). This approach, which assumed that more knowledge would build a public more supportive of science, became known as the 'Deficit Model' (e.g. Gross, 1994).

1 In what follows, we use 'Bodmer' to refer to the report and the PUS movement it engendered. 
Bodmer had also called for more science to be carried in the media, a call taken up enthusiastically by the British Broadcasting Corporation (BBC), which already had several TV and radio programs. Independent broadcasters also increased their science offerings. Newspapers responded by appointing science journalists, correspondents and editors, and some introduced special science sections into their regular pages. Particularly influential was (now Lord) Melvin Bragg, who had made his name in arts programming: his BBC Radio 4 program Start the Week regularly featured science themes and leading scientists. Debates around the notion of 'The Two Cultures', first identified as such by C. P. Snow (1959, 2012), flared into life again: was science overweening and over-powerful or was it looked down upon as being less worthy by the media and political elite who were mainly arts and literary educated? (Weldon, 1991; Wolpert, 1991; Gregory and Miller, 1998; Lock, 2016).

Political legislators and representatives were also Bodmer targets. It had been suggested that MPs and Members of the House of Lords would benefit from independent scientific advice, and in 1989 the Parliamentary Office of Science and Technology (POST) was set up with charitable funding. Parliament adopted POST three years later (and made it a permanent institution in 2001). The government set up its own Cabinet Office of Science and Technology (OST) to handle policy on science, and its report of 1993-Realising our Potential-led to UK research councils being charged with ensuring that the work they supported was communicated to taxpayers, and with setting up advisory committees to help them (UK Government, 1993).

In the higher education sector, courses in science communication were started at master's level (Imperial College, London, 1992) and undergraduate level (University College London, 1990), and graduate training was started at several universities and colleges, some paid for by the Wellcome Trust, the UK's largest funder of biomedical research. Research into PUS also gained momentum via a dedicated program by the Economic and Social Research Council. In 1992, Durant and his Science Museum colleague Jane Gregory set up the peer-reviewed journal Public Understanding of Science, which joined the renamed Science Communication to give the PUS community two outlets for scholarly research. PUS, with its twin aims of improving scientific literacy and public attitudes towards science was well on its way: the outlook was bright with just a few clouds on the horizon.

One of those clouds, however, was bovine spongiform encephalopathy (BSE) or 'mad cow disease'. At the same time that Bodmer's committee was writing its report, farmers in the UK were reporting cattle collapsing from a disease that left them staggering and slobbering across the farmyard and dying in considerable discomfort (see Jasanoff, 1997; Millstone and van Zwanenberg, 2001; Reeves, 2002; Frewer et al., 2002, for examples of 
scholarly approaches to BSE and the crisis it caused in the UK). The Central Veterinary Laboratory first recognised BSE as a novel cattle disease in 1986. At that point, the medical/scientific jury was out on just what was happening. BSE looked like scrapie, well known for affecting sheep, and officials at the Ministry of Agriculture, Food and Fisheries (MAFF) speculated that cattle being fed with protein-supplement feed containing the remains of scrapieinfected sheep were somehow catching a similar disease.

The problem was that no bacterium or virus could be found to be carrying the infection and the idea of 'prions' (Prusiner, 1982) had yet to be accepted by mainstream vets and doctors (Reeves, 2002). As concerns for human health from eating BSE-infected beef started to grow, along with media interest in what was happening down on the farm, scientists were able only to tell politicians that the chance that BSE could infect humans was 'most unlikely' (MAFF/DoH, 1989, advice cited in Beck, Asinova and Dickson, 2005), although they did advise measures to destroy infected cattle and ensure they did not enter the food chain.

In May 1990, however, the (now-defunct) middle-brow newspaper Today published two articles, one of which linked the death of a cat to BSE and one of which proclaimed: 'Scientific proof: mad cow link to humans' (Wilenius, 1990; Brough, 1990). A more serious blow was struck by the heavyweight Independent on Sunday (Nicholson-Lord, 1990), which reported that based on medical advice from its own Fellows, beef was no longer being served at Magdelene College Cambridge. The market for British beef was already in decline, and its banning from High Table was clearly a major blow.

In response, Agriculture Minister John Gummer told The Independent on Sunday that his whole family ate beef (Cannon et al., 1990), and posed with his young daughter taking bites out of beef burgers (although it is clear from the photos that it was Gummer who had bitten into both burgers). Gummer's second-in-command David McLean poured scorn on the non-beef-eaters: 'If there are some people who do not want to believe that it is safe, God help them. But let them ... not scare the vast majority of us who have common sense' (Craig and Francis, 1990; War, 1990).

While Prusiner's prion-infection theory of diseases like kuru, scrapie and BSE gradually gained traction amongst the medical community, opinions on the safety of British beef amongst scientists, politicians and the media remained divided. The 'settlement' came in 1996: on 20 March, the left-wing tabloid Daily Mirror published a scoop under the full-page headline 'MAD COW CAN KILL YOU', with an official-looking stamp on it. Later that day, Health Minister Stephen Dorrell announced to Parliament that a cluster of cases of a disease known as variant Creuzfeld-Jacob Disease in young 
people was probably linked to eating BSE-infected beef. Government advice that British beef was 'safe' had been turned on its head. Confidence in the government - seen as having misled the public for a decade over the safety of British beef-collapsed. According to the official Phillips report into the whole affair: 'When on March 20, 1996 the Government announced that BSE had probably been transmitted to humans, the public felt they had been betrayed' (Phillips, Bridgeman and Ferguson-Smith, 1997).

Just before Dorrell's announcement to parliament, Astronomer Royal Sir Arnold Wolfendale (1996) had carried out a review of PUS/science communication activities for the government. It was largely positive with few recommendations for major changes. 'Steady as you go', then. Viewing the debacle from across the Atlantic Ocean immediately after the government's volte face on BSE, Sheila Jasanoff came to a rather different conclusion: she saw a state of 'civic dislocation' in which there had been an 'unprecedented breakdown of communication' between British citizens and their government. In the dislocated state 'trust in government vanished and people looked to other institutions - the high street butcher, the restaurant, the media, the supermarket-for information and advice'. For her, British society had changed 'in profound ways that call for new forms of engagement between citizens and their government' (Jasanoff, 1997).

So how did BSE play into the era of the Deficit Model? Parallel to (but separate from) 'official' efforts to increase science communication, and hence public literacy in matters scientific, historians and sociologists of science in the UK had been pointing out that relations between citizens and research communities were much more complex than the idea that the more you tell people about science, the more they will know and the better they will like it'. The Bodmer Report had suggested that research into the efficacy of science communication activities should be funded by the Economic and Social Sciences Research Council, although their actual program owed more to pre-existing for science and technology studies (STS) than Bodmer itself. Many researchers had looked at how science was appreciated and understood by people in their everyday lives (e.g. Wynne, 1991) and how they could cope with and implement scientific advice in real-world situations (e.g. Irwin, 1995). These researchers stressed the importance of the context in which information was imparted and by whom (Layton et al., 1993). As part of this parallel discussion, Alan Gross (1994) proposed a 'contextual approach' to PUS that stressed the science we need to live plus appreciation of local knowledge and culture. 'The contextual model explores the ramifications of the interaction between science and its publics ... it depicts communication as a two-way flow, he explained (p. 6), unlike the deficit approach that stressed scientific sufficiency as against public deficiency. ${ }^{2}$

2 See also Layton et al. (1993) for further sources of these ideas. 
Looking to put some of this research into practice, in 1994 the Biotechnology and Biological Sciences Research Council (BBSRC) sponsored the Science Museum in London to run a 'consensus conference' on plant biotechnology that attempted to get more citizen involvement in science policy issues (UK Consensus Conference on Plant Biotechnology, 1994; Joss and Durant, 1995). The panel of 25 lay citizens reached a consensus that they were not against technologies to improve crop qualities and yields so long as they were well regulated and labelled. When the 1996 UK social attitudes survey found that, after a decade of Bodmerism and all the efforts it engendered, there had been little change in British scientific literacy, the deficit approach seemed clearly to be failing (see Miller, 2001, for a discussion of this). But just what was PUS/scientific literacy anyway and how might it work in the BSE situation?

In 1993, Durant had published a paper asking just that question. He looked at three possible definitions of scientific literacy: knowing a lot of science, knowing how science worked, and knowing how science really worked. Questions probing the first two definitions had made their way into the surveys used in 1989 and 1996 to see how scientific literacy was progressing. For the first definition-knowing a lot of science-the problem in the BSE case was that the 'science' in question was far from the tried-and-tested, simple textbook science that we are supposed to learn at school. Right from the first identification of BSE as a new cattle disease, there was controversy as to just what the science was-about the source of BSE, the course of BSE, and its infectiousness to humans. Knowing a lot of science might be nice, but not too helpful in this case.

The second definition—-knowing how science works—might have been more helpful. But the understanding of prion diseases and their infectious agents was at the stage of 'science in the making' and government officials were faced with immediate decisions to be made, without the benefit of long periods whilst the scientific/medical community tested one hypothesis against another. In any case, many researchers (e.g. Collins and Pinch, 1993) had shown that the 'hypothesis testing' account of the way science works often departed considerably from how it really worked, it tended to leave out much of the social context of the scientific community and how it came to judge what was and what was not good and relevant science. Understanding how science really worked was clearly not an unproblematic task; scientific literacy per se simply was not the 'answer'. Although the BSE scandal brought the (pre-)dominance of PUS/scientific literacy to a close in the UK (see Bauer et al., 2007), it did not do away with the need for good science and clear communication (Miller, 2001): it simply showed that this alone was not enough. 


\section{GM foods, the New Labour Government and the participatory turn (mid-1990s - mid-2000s)}

In the wake of the BSE scandal, 'New' Labour under Tony Blair won the May 1997 election with a huge majority (418 MPs out of a House of Commons of 659); more than half of all sitting Conservative MPs, including several ministers, lost their seats. This political sea-change marked a watershed in UK science-society relations and approaches to science communication. Drawing strongly on the ideas of Anthony Giddens and the think tank Demos, ${ }^{3}$ New Labour saw public participation as an important way to address the perceived democratic deficit, which was seen to be causing citizens to feel increasingly distant from and disillusioned with traditional decision-making structures, leading to a drop in voter turnout in elections and increasing cynicism in politics and government (Barnes et al., 2007).

Citizen participation was also seen as an important way to raise standards in public services and to find the best possible fit between user needs and service capacity. As a consequence numerous public and citizen participation opportunities and exercises arose. These ranged from the best value tendering regime, which placed a duty on local authorities to involve local citizens in reviewing services (Barnes et al., 2007), to the 'New Deal for Communities' program that involved local people in decisions about community regeneration (Smallman, 2016b). Various participatory methods such as citizens juries, deliberative polling and citizens panels were also introduced to inform local health care priority-setting decisions (Abelson et al., 2013). Giddens' influential book The Third Way described the need for more public participation in science, arguing that given the increasingly complex relationship we have with science and technology '[d] ecision making in these contexts cannot be left to the "experts", but has to involve politicians and citizens' (Giddens, 1998, p. 59). The democratisation of science and technology in this context was very much part of the process of the modernisation of government in the UK (Smallman, 2016b).

While the spectre of BSE cast a 'long shadow' (Stilgoe, 2007), the Labour government was keen to signal it had learnt lessons and moved on in its approach to dealing with the communication of public science. As Sir Robert

3 Sociologist Anthony Giddens was a pioneer of the 'Third Way' view of welfare and participation that regarded the job of government as being to give citizens a 'hand up' rather than a 'hand out', making them active citizens rather than passive recipients of welfare. His views were very influential in the Labour government under Prime Minister Tony Blair. The Demos think tank was a persuasive advocate of public participation in (scientific) decision-making, rather than leaving everything to scientific experts. 
May, the Chief Scientific Adviser at the time of the Phillips inquiry, described in his evidence, the prevailing instinct in these situations up until this episode had been 'to hold the facts close' so that a 'simple message can be taken out into the market place'. BSE, however, suggested to him that the 'full messy process whereby scientific understanding is arrived at, with all its problems, has to be spilled out into the open' (Phillips, Bridgeman and Ferguson-Smith, 2000).

Many of the themes emerging from BSE, in particular the debate about scientific uncertainty, risks and how best to communicate science to the public, were also put under the spotlight at the beginning of 1999 when genetically modified (GM) crops became a controversial issue, drawing government, scientific institutions, the public, the media and industry back into public debate.

GM crops had been rapidly introduced in the UK market from the mid1990s, prompting unease amongst green activist groups. Media coverage grew, and GM became a political issue in the House of Commons. On 12 February 1999, The Guardian published a letter from 12 scientists supporting the unpublished research of Dr Arpad Pusztai on the harmful effects of GM potatoes fed to rats (Rhodes et al., 1999). The matter became front-page news for almost two weeks. Many of the media outlets initiated high-profile campaigns against GM crops. The episode echoed the BSE controversy in several ways, not least when Prime Minister Tony Blair was quoted in a national newspaper as being happy to eat 'Frankenstein Food' and to feed it to his children; he was frustrated that the potential benefits of GM food were being ignored in the escalating row (Daily Mail, 1999).

It was in this questioning climate that the Science and Technology Select Committee of the House of Lords appointed Lord Jenkin of Roding to conduct a study into society's relationship with science (House of Lords Select Committee on Science and Technology, 2000). An earlier Lords report into the management of nuclear waste had devoted a chapter to considering the public acceptability of the issue. That report had acknowledged the complexity of public attitudes and values with respect to science and technology, the influence of the media and the importance of public trust in institutions (House of Lords Select Committee on Science and Technology, 1998). With the ongoing controversy over GM foods, and the changing nature of the scientific advisory processes within government in response to the BSE affair, Jenkin's team examined both the sources of information that shaped public attitudes to science and the mechanisms for facilitating dialogue between scientists and the rest of society. Notable in the production of this report was the appointment of Durant and STS academic Brian Wynne, who had been openly critical of the prevailing approaches to science communication for many years, as special advisors. 
The final report, Science and Society, was published in February 2000, and concluded that society's relationship with science was in a critical phase. A 'crisis in confidence' on the part of the public, was how the committee characterised the relationship between science and society; and it put forward many different recommendations as to how this relationship could be improved, not least by advocating a shift away from 'simply giving information' to 'engaging the wider public in dialogue about what science could and should be doing' (p. 13). There was, however, a tension within the report: dialogue and engagement meant assigning a level of legitimacy to the public, allowing public values to be considered, and opening up the science policymaking process; in other senses, it appeared more to do with listening to the public's attitudes, and then, having done so, science could be trusted to get on with scientific research. As the report emphasised, dialogue was intended to secure science's licence to practice, not to restrict it-thus the scientific experts maintained authority and responsibility over science.

The effects of these recommendations were both quick and widespread, with science communication and scientific institutions in the UK (for example, the RS and the Research Councils) shifting the focus of existing programs in PUS or science communication to 'science in/and society' programs, prioritising dialogue exercises over more traditional one-way transmission activities. Perhaps the most obvious of all institutional changes, and a sign of how much the House of Lords report had changed both the landscape and language used in a short space of time, was the reformulation of COPUS. Following extensive reviews of the committee in the previous two years, it was agreed by all the partners that COPUS should be remodelled in this new climate as 'an inclusive partnership between the many sectors now involved in communicating science' (Lock, 2011). COPUS was now no longer to be used as an acronym, but as a brand 'Copus', with a new expanded council reflecting a broader range of stakeholders in science communication than the original three founding bodies. Chaired by Bridget Ogilvie, previously chief executive of the Wellcome Trust, the new body was intended to oversee science communication at a national level. But it was made clear that this was not to be one-way science communication; instead, it was to be focused on 'supporting ways of increasing public engagement with the issues and processes of science' (p. 25). The COPUS grant schemes were also reformulated under this new agenda to fund efforts at dialogue with the public.

Commitment to dialogue and debate was soon put to the test: in 2002, the UK government set up the first nationwide public dialogue on the heated issue of GM foods (Rowe et al., 2005). The Agriculture and Environment Biotechnology Commission had previously concluded that the development of GM crops had 'suffered as a result of the lack of opportunity for serious 
debate about the full range of potential implications of GM agriculture, on the basis of clear understandings of what is involved, away from concern that had been created by campaigning elements of the media'. Consequently, they argued that the government needed to 'encourage comprehensive public discussion of the ecological and ethica-including socioeconomic-issues which now have arisen' (AEBC, 2001).

Comprising a series of open public meetings, a dedicated debate website and a series of closed discussions (which acted as control groups), the GM Nation debate ran over the summer of 2003 and is believed to have reached more than 20,000 people (Rowe et al., 2005). Its stated aims were twofold:

To promote an innovative, effective and deliberative programme of debate on GM issues, framed by the public, against the background of the possible commercial production of GM crops in the UK and the options for possibly proceeding with this; and through the debate provide meaningful information to Government about the nature and spectrum of the public views, particularly at grass roots level, on the issue to inform decision-making (PDSB, 2003).

'GM Nation?' was an 'unprecedented', and therefore experimental, national event in public dialogue. From a number of perspectives, however, it 'failed'. For the government and some scientists, it was seen to do little to take the heat out of the GM debate (Gaskell et al., 2004; Horlick-Jones et al., 2006). Others argued that it was impeded by lack of time and money (House of Commons, Environment, Food and Rural Affairs Committee, 2003), that it failed to engage with a sufficiently wide array of people, that it was primarily a legitimatory exercise and that it lacked focus (Irwin et al., 2012; Council for Science and Technology, 2005; House of Commons, Environment, Food and Rural Affairs Committee, 2003).

The GM debate was also seen to be foreshadowing a controversial emerging science-nanoscience. Although the UK was leading the way in this promising new field, would public opposition curtail it? In See through Science (Wilsdon and Willis, 2004), Demos used the launch of a report on nanoscience from the RS and Royal Academy of Engineering (Royal Academy of Engineering and the Royal Society, 2004) as the backdrop against which to make the case for 'upstream engagement', using this as an opportunity to correct the mistakes that were made with GM. In part to forestall any potential public opposition to this new area of science, the UK government launched the ScienceWise program in 2004, to encourage, fund and support policymakers to involve the public in decisions around science and technology. At the same time COPUS and its grant schemes was wound down and retired. 
The ScienceWise scheme was launched to 'build the capacity of citizens, the science community and policymakers to engage in the dialogue necessary to establish and maintain public confidence in making better choices about critical areas in science and technology' (HM Treasury 2004, p. 108). The focus of PUS and related science communication activities had been firmly on increasing the amount of scientific knowledge and understanding that the public held, yet the effect of the BSE and GM crops controversies had shifted the focus onto issues of scientific advice and public trust in science and scientists; and dialogue and consultation were seen as the new orthodoxy in science policy and communication circles.

The switch of funding from 'traditional' science communication to processes that involved the public over policy-relevant issues had had its effect on the community. For example, the BSA was struggling to change itself to fit with the new dialogue and policy-oriented approach to science-society relationships. A review of strategy had developed a new purpose for the association-'to create a positive social climate in which science, and organisations dependent on it, advances with public consent, involvement and active support'moving it away from its previous focus on science communication and public understanding (British Association for the Advancement of Science, 2005). Their 2005 annual Science Communication Conference was a fractious affair with a clear division between those individuals and organisations there to discuss practical efforts to improve science communication and those interested in discussing dialogue and influencing government policy.

As the drift from deficit to dialogue became a surging tide, criticism began to emerge. There was much discussion about the representativeness of the participants and whether dialogue was meant to represent existing views or to help to form new ones (Lezaun and Soneryd, 2007). Evaluations of dialogue activities highlighted how little impact they had on policy and that the objectives of science often went unchallenged at these events. Critics argued that the events themselves worked on the assumption that science is an inherent good, and limited public participation to voicing aspirations and concerns, rather than discussing the type of world that the particular science or technology was building (Macnaghten, Kearnes and Wynne, 2005; Wynne, 2006; Smallman, 2017).

\section{MMR to post truth}

While the period from the late 1990s to the mid-2000s has been characterised here and elsewhere (for instance, Stilgoe et al., 2014; Irwin, 2014; Smallman, 2014) as a move from deficit to dialogue, it is important to recognise that 
other, more 'traditional' science communication activities, aiming to explain science to the general public, have nonetheless continued to take place-and to flourish. The British Association for the Advancement of Science (BA) has continued to run its annual meeting in September of each year and its National Science Week (renamed British Science Week in 2014) in March; the Edinburgh Science Festival has taken place each spring. In 2002, Frank Burnet and Kathy Sykes, science communication academics and practitioners based in Bristol, launched the Cheltenham Science Festival. This became well known for originating the global FameLab contest, which invites scientists to compete in the style of TV's X Factor to give the best public talk. Science festivals have since mushroomed across the UK-from Brighton to Dundee-such that there were more than 30 science festivals involved in the UK Science Festivals Network in 2018.

Activities to encourage school children to take up careers in science and technology have also remained an important feature of the UK's science communication landscape. The RS continues to open its doors to the public every July for its annual Summer Exhibition, attracting several thousand school visitors in 2017. In 2006 Engineering UK organised the first Big Bang Fair, which aimed to show young people the exciting and rewarding opportunities out there [in science] for them'. Claiming to be the 'largest celebration of STEM for young people in the UK', the fair attracted 80,000 visitors in 2018 (Big Bang: UK Young Scientists and Engineers Fair, 2018). Since 2013, however, the event has been subject of criticism for the heavy involvement of arms manufacturers and fossil fuel companies (e.g. Bell, 2013).

In this spirit of explaining science to the public and sharing scientists' enthusiasm for their subjects, the citizen science movement also grew significantly in the UK during the 1990s and early 2000s. While Alan Irwin's original conception of citizen science as a way to create more active 'scientific citizenship' by bring the public and science closer together through dialogue and decision-making around environmental risks (Irwin, 1995), it has become a term to refer to involving citizens in the 'doing' of science-at least in part to help share scientists' enthusiasm for their subjects. Typically, citizens are involved in gathering or analysing large amounts of data. For example, the BBC and The Daily Telegraph set up the MegaLab in 1995, which, led by Prof. Richard Wiseman of the University of Hertfordshire, used national television, radio and press (BBC1's Tomorrow's World, BBC Radio One and The Daily Telegraph) to test whether it is easier to detect lies in print, radio or TV (Wiseman, 1995). In 2014, 'citizen science' was added to the Oxford English Dictionary (Bonney et al., 2016) and today is the subject of activities from scientific establishment organisations ranging from the BSA to the National Endowment for Science, Technology and the Arts (NESTA). 
Reflecting the dual purpose-democratising science and promoting sciencethat has arisen within science communication in the UK in the early 21 st century, the term 'public engagement' came into popular use amongst the community in the early 2000s (Suerdem et al., 2013). This term-which implies both capturing the public's attention and involving them in decisions about science without actually specifying either-was a compromise that dissipated tensions between these two different viewpoints within the community. A debate that took place on the psci-comm mailing list, titled 'the Importance of Public Understanding of Science' in May 2001around the time of the 'move' from deficit to dialogue-illustrates this well. ${ }^{4}$ Key figures from science and society discussed how on one hand the term 'engagement' showed the new bottom-up approach to 'science and society' relations, while on the other hand it disguised the PR nature of many science communication activities. However, no one disagreed that engagement was a better term than PUS.

Cementing engagement as the agreed compromise-and burying any possible tensions between the two approaches to science and society even deeper-in 2008, the Higher Education Funding Councils, Research Councils UK and the Wellcome Trust funded a series of six 'Beacons of Public Engagement' and a National Coordinating Centre for Public Engagement (NCCPE). The six beacons-based in Wales, Edinburgh, East Anglia, Manchester, North East England and UCL_-were 'university-based collaborative centres that were set up to support, recognise, reward and build capacity for public engagement' (NCCPE, 2018). Funded for four years, the beacons aimed to encourage a culture change in UK universities, to open them up to engagement with the wider public.

The beacons adopted a broad definition of public engagement, to encompass 'a whole family' of types of engagement. Reflecting this, the beacons - and the subsequent 'Catalysts for Public Engagement'-have driven forward a wide variety of science communication activities ranging from Steve Cross's UCL-based 'Bright Club', 5 where UCL academics were trained to perform stand-up comedy about their work, to Swansea University's 'Little Voices Shouting Out / Lleisiau Bach yn Galw Allan' project that supports children to carry out research on issues that matter to them and to present their findings to policymakers (Little Voices, 2018). The NCCPE itself has also developed best practice guidance for universities, the annual 'Engage' conference and a journal.

4 See www.jiscmail.ac.uk/cgi-bin/wa-jisc.exe?A1=ind01\&L=PSCI-COM.

5 See www.ucl.ac.uk/culture/projects/bright-club. 
Over time, a number of these traditional science communication events have changed shape and focus, often reflecting debates taking place in the more dialogic arm of science in public. In 2018, for example, under the leadership of Chief Executive Katherine Mathieson, the BSA launched a new mission 'to transform the diversity and inclusivity of science; to reach under-served audiences, and increase the number of people who are actively engaged and involved in science' (British Science Association, 2018). Similarly, Muki Haklay at UCL developed a new format of citizen science that moves closer to Irwin's original democratising idea. In Haklay's 'extreme citizen science', scientists and non-scientists (or professional and non-professional scientists, as he terms these two groups) work together to decide the scientific problems to work on and how to collect and validate data (Haklay, 2013). Nevertheless, the purpose of sharing scientists' enthusiasm for science has remained.

\section{The pushback against dialogue}

Despite these moves to bridge the divide between science promotion and democratisation, many scientists continued to hold the view that the media was misrepresenting science and influencing public opinion inappropriately. These tensions came to the surface around the time of public debates about the safety of combined MMR (measles, mumps and rubella) vaccines, GM foods and mobile phones in the early 2000s. In particular, media-driven concerns about the safety of the combined MMR vaccine-concerns unsupported by the majority of the biomedical community-led to large numbers of (particularly middle class) parents refusing to have their child vaccinated. As a result, there were a series of local epidemics of measles, in which a number of young children died.

In January 2002, Liberal Democrat Peer Lord Dick Taverne and former Wellcome Trust Director Brigit Oglivy had launched the organisation 'Sense about Science', which aimed to 'put evidence at the heart of public discussion'. On the launch of Demos' 2005 See Through Science report, Taverne made clear his opposition to moves to democratise science, writing a letter to the journal Nature subtitled 'We must face the fact that science-like art-is not a democratic activity'. His letter asserted: 'You do not decide by referendum whether the Earth goes round the Sun' (Taverne, 2004). 'Sense about Science' has since developed an 'Evidence Base': a database of experts who want to put good science at the heart of public discussion; and a series of 'making sense of ...' briefings that guide the public on what questions to ask about scientific issues. It has intervened in a number of public controversies including MMR and GM. 
Around the same time (2002), the Science Media Centre (SMC) was launched. Housed at the Royal Institution, yet independent from both it and the government and led by Director Fiona Fox, the SMC proposed to take a proactive stance by providing science stories, and scientists, to the media where they felt there was 'a public interest or a developing controversy'. Its mission statement claimed to 'provide a focal point for scientists to explain the nature of their work, discuss its consequences, and engage in public discussion over the benefits and risks'. The website of the SMC claimed to trace its roots back to the desire of the House of Lords' Science and Society report (2000), 'to renew public trust in science'. (The Lords' report had largely concluded that the scientific community should deal with the media as it was, rather than seek to change how it operates.)

The establishment of the SMC was, on the one hand, a sign that members of the scientific community were following this and trying to deal with the media on its own terms, through effective communication. On the other hand, the move could equally be interpreted as an indication that some within the scientific community were still angling for more control over media messages about science-for example, by being able to field the 'right' scientists to communicate particular messages. Communication of accurate science was seen as the means of improving the relationship between the two, as the SMC's current aim proposes 'supporting them [scientists] to engage with the media; creating more opportunities for them to get their voices heard on the big science, health and environment stories of the day' (SMC, n.d.). For all the 'Sense about Science' and SMC efforts, paradoxically it was to be a journalist, Brian Deer, who did most to debunk the MMR scandal in the public mind, exposing Andrew Wakefield, the researcher who first suggested there was evidence to question the safety of the vaccine, as being in the pay of lawyers acting for families suing the National Health Service (see Deer, 2009, for example).

Moves to take hold of the agenda did build some momentum in the mid2000s: Ben Goldacre wrote a popular 'Bad Science' column in the Guardian from 2003 to 2011, highlighting instances of pseudoscience and the misuse of science. In 2012, biology student Elise Andrews set up the Facebook Group 'I f***ing Love Science', attracting more than a million 'likes' in its first year-ostensibly from its posts presenting interesting and amusing facts about science, but also because sharing posts from the site allowed people to demonstrate their scientific and rational identities and their belonging to this 'tribe' (Marsh, 2018). The former Times science writer Mark Henderson authored the popular book The Geek Manifesto - Why science matters in 2013. 
It drew again on media scares around GM crops, vaccines and nuclear power. The Geek Manifesto advocated for more scientific thinking in public life, this time giving it a more activist edge, claiming:

Something is stirring among those curious kids who always preferred sci-fi to celebrity magazines. As the success of Brian Cox and Ben Goldacre shows, geeks have stopped apologising for an obsession with asking how and why, and are starting to stand up for it instead. The Geek Manifesto shows how people with a love of science can get political, to create a force our leaders can no longer afford to ignore (p. 12).

\section{Responsible research and innovation}

In parallel to the 'fightback' initiatives, however, there have been efforts to make science and scientific research agendas even more, not less, public property, areas of legitimate interest and concern for 'ordinary' citizens. The concept of responsible research and innovation (RRI) developed in the late 2000s under the auspices of the European Commission (see Smallman, 2018, for a discussion on the relationship between citizen science and RRI). In 2011, the Commission developed and adopted a concept of RRI that built upon the earlier ideas around public participation and dialogue, but with the aim of involving all actors (not just citizens or experts) throughout the process of innovation such that science could be more firmly rooted in society and society's needs and ambitions (Owen et al., 2012). This heralded a move from 'science in society' to 'science with and for society' (Laroche, 2011) and RRI was introduced as a cross-cutting theme of the Horizon2020 program. In RRI, science communication was seen as one of six key strands rather than a standalone activity.

Several UK institutions took up the challenge of RRI, most notably, the Societal Issues Panel of the Engineering and Physical Sciences Research Council (EPSRC). This panel had been set up in the wake of the GM debate, with the aim of identifying future issues of concern. The panel invited Richard Owen, then Professor of Responsible Innovation at the University of Exeter, to help them develop a more general framework for researchers. In 2013 their framework for Responsible Innovation, based on the principles of Anticipation, Reflection, Engage and Act (AREA) was published (Miller, 2016). Shortly after publishing this framework, the EPSRC (with the BBSRC) put out a call to fund a series of synthetic biology research centres that would include specific work on RRI. Those on the assessment panel, which included Owen, reported that the proposals had taken up the 
AREA approach and embedded RRI (and public dialogue) within their sense of 'excellent research', producing more imaginative and interesting research proposals (Miller, 2016).

While it is very much an approach to governing emerging technologies, RRI has had significant implications for science communicators involved in public participation. The concept has arguably shifted the role of the science communicator from one who explains science to the public, to one who helps scientists and technology developers understand society. Arguably the objective of helping science to succeed remains, but it is achieved by helping science do more socially acceptable research.

\section{Brexit and the post-truth era}

On 2 June 2016, in the run up to the UK European Referendum, former education minister Michael Gove was challenged on television to name any economic experts who supported his position to leave the European Union. Refusing to answer the question, he replied: 'People in this country have had enough of experts (Gove, 2016).' This comment sent a chill down the spine of many scientists, leading many once again to seek better science communication, and the reassertion of expertise and reason, as the answer to many of the world's problems. New Scientist ran an editorial in June 2016, summing up this sentiment with the headline 'Post Brexit, experts need to reassert their value to society'. In it they called for scientists to improve their communication skills so that they can 'speak the emotional language of the victors' (New Scientist, 2016).

Others offered more nuanced positions-for instance, Tracy Brown from 'Sense about Science' argued that there was no evidence to support claims of falling support for experts (Brown, 2016). Others still suggested that Michael Gove's comment resonated with the public only because such a gulf had arisen between expert accounts of the world—including the impacts of science and technology — and the day-to-day experiences of ordinary people. Listening to the public more and involving more diverse perspectives in scientific and technological developments would be the answer to avoiding future troubles (Smallman, 2016a). 


\section{Conclusions}

The timeline for science communication and science and society relations in the UK shows that this is far from a linear story. There are repeating cycles of activity as one or other of the various strands we have identified come to the fore or retreat into the background: at no time does any theme we have identified come to a complete end; at no time does the prevalent 'model' completely supersede what has gone before-there is no 'death of the dinosaurs' event that consigns a whole ecosystem of science communication to the fossil record. Instead, ecosystems evolve both independently and interactively at different times, at different rates of 'progress'.

In many ways, the UK is an exemplar of-sometimes even a driver ofchanging science communication landscapes further afield than its own national borders. This is particularly the case across the European Union, where programs on Raising Public Awareness of Science and Technology (1999-2004, essentially PUS-plus) were replaced by science-and-society and then science-with-and-for-society as dialogue and debate and other engagement-oriented approaches came forward in the UK.

Although many of the main strands exist, develop and co-exist with one another, there are changes nonetheless. In the UK science communication training for researchers-workshops, courses, programs-has developed alongside demands in government for science to have demonstrable - and measurable-impact. Research council (and other) funding has helped to provide incentives for this. To an extent these efforts have been institutionalised in, for example, the National Coordinating Centre for Public Engagement, which allowed the beacons projects to develop and the Research Excellence Framework (REF) that gives additional funding to institutions that can demonstrate 'impact'. But it is also-typical of the UK-a story of many activities by individuals and individual groups and institutions.

If we are to draw just one lesson from our study of science communication in the UK it is that there is no one 'right way'. Having a genuine landscape inhabited by a multi-faceted ecosystem means that models, approaches and activities can come to the fore and fade into the background as the circumstances demand. 


\section{References}

Abelson, J., Blacksher, E., Li, K., Boesveld, S. and Goold, S. (2013). Public deliberation in health policy and bioethics: Mapping an emerging, interdisciplinary field. Journal of Public Deliberation, 9(1), Article 5.

Agar, J. (2011). Thatcher: Scientist. Notes Rec. 65, 215-32. doi.org/10.1098/rsnr. 2010.0096.

Agriculture and Environment Biotechnology Advisory Board. (AEBC). (2001). Crops on Trial: A Report by the AEBC. London: AEBC.

Barnes, M., Newman, J. and Sullivan, H. C. (2007). Power, participation and political renewal: Case studies in public participation. Bristol: Policy Press. doi.org/ $10.2307 /$ j.ctt9qgrqs.

Bauer, M., Allum, N. and Miller, S. (2007). What can we learn from 25 years of PUS survey research? Liberating and expanding the agenda. Public Understanding of Science, 16, 79-95. doi.org/10.1177/0963662506071287.

Beck, M., Asinova, D. and Dickson, G. (2005). Science and Risk Assessment: A case study of the UK Bovine Spongiform Encephalopathy Crisis. Public Administration Review, 65(4), 396-408.

Bell, A. (2013, 18 March). The Big Bang Fair: A depressing vision of science and engineering. The Guardian.

The Big Bang: Young Scientists and Engineers Fair. (2018). 80,000 visitors attend The Big Bang Fair 2018. Retrieved from www.thebigbangfair.co.uk/news/mediaand-press/press-releases/80-000-visitors-attend-the-big-bang-fair-2018/.

Bonney, R., Phillips, T. B., Ballard, H. L. and Enck, J. W. (2016). Can citizen science enhance public understanding of science? Public Understanding of Science, 25(1), 2-16. doi.org/10.1177/0963662515607406.

British Association for the Advancement of Science. (2005). Connecting Science: What we know and what we don't know about science in society. London: The British Association for the Advancement of Science.

British Science Association. (2018). Revolutionising people's relationship with science. Retrieved from www.britishscienceassociation.org/news/introducing-our-newstrategy.

Brough, G. (1990, 16 May). Scientific proof: Mad cow link to humans. Today, p. 1.

Brown, T. (2016, 19 September). The idea of a post-truth society is elitist and obnoxious. The Guardian. Retrieved from www.theguardian.com/science/blog/ 2016/sep/19/the-idea-post-truth-society-elitist-obnoxious.

Cannon, G., Connor, S., Hague, H. and Nicholson-Lord, D. (1990). Mad cows and Englishmen. Independent on Sunday, May 20, p. 19. 
Collins, H. and Pinch, T. (1993). The Golem: What you should know about science. Cambridge: Cambridge University Press.

COPUS. (2001). A new direction for COPUS. Retrieved from www.copus.org.uk/ copus_councilpaper.htm.

Council for Science and Technology. (2005). Policy through dialogue. Retrieved from webarchive.nationalarchives.gov.uk/20130705054945/http://www.bis.gov. uk/assets/cst/docs/files/whats-new/05-2180-policy-through-dialogue-report.pdf.

Craig, O. and Francis, W. (1990). We were frightened then Gummer rang. Today, May 16, p. 5.

Daily Mail. (1999). The Prime Monster. Fury as Blair says: I eat Frankenstein food and it's safe. February 16, pp. 1-2.

Daily Mirror. (1996). Mad Cow can kill you. March 20, pp. 1-2.

Dawkins, R. (1996). Richard Dimbleby Lecture, BBC TV. Retrieved from www. youtube.com/watch?v=7hEwYhMhdO8.

Deer, B. (2009, 8 February). MMR doctor Andrew Wakefield fixed data on autism. The Times. Retrieved from www.thetimes.co.uk/article/mmr-doctor-andrewwakefield-fixed-data-on-autism-mgj82qsk50g.

Department of Health, and Ministry of Agriculture, Fisheries and Food (DOH/ MAFF). (1989). Report of the Working Party on Bovine Spongiform Encephalopathy ('Southwood Report'). London: UK Department of Health.

Durant, J. R. (1993). What is scientific literacy? In J. R. Durant and J. Gregory (eds), Science and culture in Europe. London: Science Museum.

Durant, J. R., Evans, G. A. and Thomas, G. P. (1989). The public understanding of science. Nature, 340, 11-14. doi.org/10.1038/340011a0.

Frewer, L., Miles, S., Brennan, M., Kuznesof, S., Ness, M. and Ritson, C. (2002). Public preferences for informed choice under conditions of risk uncertainty. Public Understanding of Science, 11, 363-72.

Gaskell, G., Allum, N., Wagner, W., Kronberger, N., Torgersen, H., Hampel, J. and Bardes, J. (2004). GM foods and the misperception of risk perception. Risk Analysis: An International Journal, 24, 185-94. doi.org/10.1111/j.0272-4332.2004.00421.x.

Giddens, A. (1998). The Third Way: The renewal of social democracy. Cambridge: Polity Press.

Gove, M. (2016, 3 June). Interview with Faisal Islam on Sky News. Retrieved from en.wikiquote.org/wiki/Michael_Gove.

Gregory, J. and Miller, S. (1998). Science in public: Communication, culture and credibility (pp. 45-51). New York: Perseus/Basic Books. 
Gross, A. G. (1994). The roles of rhetoric in the public understanding of science. Public Understanding of Science, 3, 3-23. doi.org/10.1088/0963-6625/3/1/001.

Guise, G. (2014). Margaret Thatcher's influence on British science. Notes Rec. 68, 301-09. doi.org/10.1098/rsnr.2013.0067.

Haklay, M. (2013). Citizen science and volunteered geographic information: Overview and typology of participation. In D. Sui, S. Elwood and M. Goodchild (eds), Crowdsourcing Geographic Knowledge (pp. 105-22). Dordrecht: Springer. doi.org/10.1007/978-94-007-4587-2_7.

Henderson, M. (2013). The Geek Manifesto - Why science matters. London: Corgi Books.

HM Treasury. (2004). Science \& innovation investment framework 2004 - 2014. London: HMSO.

Horlick-Jones, T., Walls, J., Rowe, G., Pidgeon, N., Poortinga, W. and O'riordan, T. (2006). On evaluating the GMNation? Public debate about the commercialisation of transgenic crops in Britain. New Genetics and Society, 25, 265-88. doi.org/ 10.1080/14636770601032858.

House of Commons, Environment, Food and Rural Affairs Committee. (2003). Conduct of the GM Public Debate, Eighteenth Report of Session 2002-3. London: HMSO.

House of Lords Select Committee on Science and Technology. (1998). Management of Nuclear Waste, 3rd Report. Session 1998-1999, HL Paper 41. London: HMSO.

House of Lords Select Committee on Science and Technology. (2000). Science and Society. London: HMSO.

Irwin, A. (1995). Citizen Science: A study of people, expertise and sustainable development. London, New York: Routledge.

Irwin, A. (2014). From deficit to democracy (revisited). Public Understanding of Science, 23(1), 71-6.

Irwin, A., Jensen, T. E. and Jones, K. E. (2012). The good, the bad and the perfect: Criticizing engagement practice. Social Studies of Science, 43(1), 118-35. doi.org/ 10.1177/0306312712462461.

Jasanoff, S. (1997). Civilization and madness: The great BSE scare of 1996. Public Understanding of Science, 6, 221-32. doi.org/10.1088/0963-6625/6/3/002.

Joss, S. and Durant, J. (1995). The UK National Consensus Conference on Plant Biotechnology. Public Understanding of Science, 4, 195-204. doi.org/10.1088/ 0963-6625/4/2/006.

Laroche, G. (2011). Responsible Research and Innovation from an EU Commission's perspective. Retrieved from www.ambafrance-uk.org/IMG/pdf/ Gilles_LAROCHE.pdf. 
Layton, D., Jenkins, E., McGill, S. and Davey, A. (1993). Inarticulate science: Perspectives on the public understanding of science and some implications for science education. Leeds: Leeds Media Services.

Lezaun, J. and Soneryd, L. (2007). Consulting citizens: Technologies of elicitation and the mobility of publics. Public Understanding of Science, 16, 279-97. doi.org/ 10.1177/0963662507079371.

Little Voices. (2018). Little Voices Shouting Out / Lleisiau Bach yn Galw Allan. Retrieved from www.publicengagement.ac.uk/do-engagement/inspire-me/casestudies/little-voices.

Lock, S. J. (2011). Deficits and dialogues: science communication and the public understanding of science in the UK. In D. J. Bennett and R. C. Jennings (eds), Successful science communication: Telling it like it is (pp. 17-30). Cambridge: Cambridge University Press.

Lock, S. J. (2016). Cultures of incomprehension? The legacy of the Two Cultures debate at the end of the twentieth century. Interdisciplinary Science Reviews, 41, 148-66.

Macnaghten, P., Kearnes, M. and Wynne, B. (2005). Nanotechnology, governance, and public deliberation: What role for the Social Sciences? Science Communication, 27(2), 268-91. doi.org/10.1177/1075547005281531.

Marsh, O. M. (2018). Nah, musing is fine. You don't have to be 'doing science': Emotional and descriptive meaning-making in online non-professional discussions about science ( $\mathrm{PhD}$ thesis). University College London.

Miller, S. (2001). Public understanding of science at the crosssroads. Public Understanding of Science, 10, 115-20.

Miller, S. (2016). Training Showcase: The UK's Engineering and Physical Sciences Research Council's Framework for Responsible Innovation. RRI Tools. Retrieved from www.rri-tools.eu/documents/10184/193151/2_RRITOOLSEPSRC_Showcase_final.pdf/2189f09b-4d83-4425-92c6-3ff8e8129639.

Millstone, E. and van Zwanenberg, P. (2001). Politics of expert advice: Lessons from the early history of the BSE saga. Science and Public Policy, 28, 99-112. doi.org/ $10.3152 / 147154301781781543$.

National Co-ordinating Centre for Public Engagement (NCCPE). (2018). Beacons for Public Engagement. Retrieved from www.publicengagement.ac.uk/nccpeprojects-and-services/completed-projects/beacons-public-engagement.

New Scientist. (2016, 29 June). Post Brexit, experts need to reassert their value to society. Retrieved from www.newscientist.com/article/mg23130803-500-postbrexit-experts-need-to-reassert-their-value-to-society/.

Nicholson-Lord, D. (1990, 30 September). It's a mad, mad, diet of MAFF-speak. Independent on Sunday, p. 4. 
Owen, R., Macnaghten, P. and Stilgoe, J. (2012). Responsible research and innovation: From science in society to science for society, with society. Science and Public Policy, 39(6), 751-60. Oxford University Press. doi.org/10.1093/scipol/scs093.

Phillips N., Bridgeman, J. and Ferguson-Smith, M. (1997). The BSE Inquiry Report: Volume 1. London: HMSO.

Phillips, N., Bridgeman, J. and Ferguson-Smith, M. (2000). The BSE Inquiry Report: Evidence and Supporting Papers of the Inquiry into the Emergence and Identification of Bovine Spongiform Encephalopathy. London: HMSO.

Prusiner, S. B. (1982). Novel proteinaceous infectious particles cause scrapie. Science, 216, 136-44. doi.org/10.1126/science.6801762.

Public Debate Steering Board (PDSB). (2003). GM Nation? The findings of the Public Debate. Report of the Public Debate Steering Board. London: Department of Trade and Industry.

Reeves, C. (2002). An orthodox heresy: Scientific rhetoric and the science of prions. Science Communication, 24, 98-122. doi.org/10.1177/107554700202400105.

Rhodes J. et al. (1999, 12 February). Letter. The Guardian, p. 7.

Rowe, G., Horlick-Jones, T., Walls, J. and Pidgoen, N. (2005). Difficulties in evaluating public engagement initiatives: Reflections on an evaluation of the UK GM nation? Public debate about transgenic crops. Public Understanding of Science, 14, 331-52. doi.org/10.1177/0963662505056611.

Royal Academy of Engineering and the Royal Society. (2004). Nanoscience and nanotechnologies: Opportunities and uncertainties. London: Royal Society.

Royal Society. (1985). The Public Understanding of Science (Bodmer Report). London: Royal Society.

Science Media Centre (SMC). (n.d.). About us. Retrieved from www.science mediacentre.org/about-us/.

Smallman, M. (2014). Public understanding of science in turbulent times III: Deficit to dialogue, champions to critics. Public Understanding of Science, 25(2), 186-97. doi.org/10.1177/0963662514549141.

Smallman, M. (2016a). Make innovation more equitable to restore trust in experts. Research Fortnight. London.

Smallman, M. (2016b). What has been the impact of public dialogue in science and technology on UK policymaking? ( $\mathrm{PhD}$ thesis). University College London. Retrieved from discovery.ucl.ac.uk/1473234/.

Smallman, M. (2017). Science to the rescue or contingent progress? Comparing ten years of public, expert and policy discourses on new and emerging science and technology in the UK. Public Understanding of Science, 27(6), 655-73. doi.org/ $10.1177 / 0963662517706452$. 
Smallman, M. (2018). Citizen science and responsible research and innovation. In S. Hecker, M. Haklay, A. Bowser, Z. Makuch, J. Vogel and A. Bonn (eds), Citizen science: Innovation in open science, society and policy. UCL Press: London. doi.org/10.2307/j.ctv550cf2.24.

Snow, C.P. (1959/2012). The two cultures. Cambridge: Canto Classics.

Stilgoe, J. (2007). The (co-)production of public uncertainty: UK scientific advice on mobile phone health risks. Public Understanding of Science, 16, 45-61. doi.org/ $10.1177 / 0963662506059262$.

Stilgoe, J., Lock, S. J. and Wilsdon, J. (2014). Why should we promote public engagement with science? Public Understanding of Science, 23(1), 4-15.

Suerdem, A., Bauer, M. W., Howard, S. and Ruby, L. (2013). PUS in turbulent times II - A shifting vocabulary that brokers inter-disciplinary knowledge. Public Understanding of Science, 22(1), 2-15. doi.org/10.1177/0963662512471911.

Taverne, D. (2004). Let's be sensible about public participation. Nature, 432, 271. doi.org/10.1038/432271a.

UK Consensus Conference on Plant Biotechnology. (1994). Final Report. London: Science Museum.

UK Government. (1993). Realising our potential: A strategy for science, engineering and technology. London: HMSO.

War, S. (1990, 9 June). Loophole allows export of 'Mad Cow' beef. The Independent, p. 3.

Weldon, F. (1991, 2 December). Thoughts we dare not speak aloud. The Daily Telegraph, p. 14.

Wilenius, P. (1990, 11 May). Mad Cows' Disease kills cat. Today, p. 1.

Wilsdon, J. and Willis, R. (2004). See-through science: Why public engagement needs to move upstream. London: Demos.

Wiseman, R. (1995). The megalab truth test. Nature, 373(6513), 391. doi.org/ 10.1038/373391a0.

Wolfendale, A. (1996). Report of the Committee to review the contribution of scientists and engineers to the public understanding of science. London: HMSO.

Wolpert, L. (1991, 9 December). So much for artistic license. The Daily Telegraph, p. 12.

Wynne, B. (1991). Knowledges in context. Science, Technology and Human Values, 16, 111-121. doi.org/10.1177/016224399101600108.

Wynne, B. (2006). Public engagement as a means of restoring public trust in sciencehitting the notes, but missing the music? Community Genetics, 9(3), 211-20. doi.org/10.1159/000092659. 


\section{Timeline}

\begin{tabular}{|c|c|c|c|}
\hline Event & Name & Date & Comment \\
\hline $\begin{array}{l}\text { First interactive } \\
\text { science centre } \\
\text { established. }\end{array}$ & $\begin{array}{l}\text { The first purpose-built } \\
\text { independent science } \\
\text { centre in the UK was } \\
\text { Techniquest in Cardiff }\end{array}$ & $\begin{array}{l}13 \\
\text { November } \\
1986\end{array}$ & $\begin{array}{l}\text { 1931: Interactive exhibits in the } \\
\text { Children's Gallery at Science } \\
\text { Museum in London from } 1931 . \\
\text { 2000: New science centres- } \\
\text { including the National Space } \\
\text { Centre in Leicester, and } \\
\text { Dynamic Eart in Edinburgh- } \\
\text { were opened with funds from } \\
\text { the Millennium Foundation }\end{array}$ \\
\hline \begin{tabular}{l|} 
First national \\
(or large regional) \\
science festival.
\end{tabular} & \begin{tabular}{|l|} 
This event in York, \\
turned out to be the \\
first annual meeting of \\
the British Association \\
for the Advancement of \\
Science (BAAS) (now \\
the British Science \\
Association, BSA) \\
\end{tabular} & $\begin{array}{l}26 \\
\text { September } \\
1831\end{array}$ & $\begin{array}{l}\text { 1943: BAAS ran its annual } \\
\text { meeting specially themed on } \\
\text { 'Science for the Citizen', later } \\
\text { the title of a bestselling book } \\
\text { by Lancelot Hogben. } \\
\text { 1989: Edinburgh Science } \\
\text { Festival, first regional science } \\
\text { festival }\end{array}$ \\
\hline $\begin{array}{l}\text { An association } \\
\text { of science } \\
\text { writers or } \\
\text { journalists or } \\
\text { communicators } \\
\text { established. }\end{array}$ & $\begin{array}{l}\text { The Association of } \\
\text { British Science Writers } \\
\text { was founded by J. G. } \\
\text { Crowther and Maurice } \\
\text { Goldsmith }\end{array}$ & $\begin{array}{l}3 \text { March } \\
1947\end{array}$ & $\begin{array}{l}\text { Crowther was a science } \\
\text { journalist on the Manchester } \\
\text { Guardian and Goldsmith of } \\
\text { Reynolds News (last published } \\
18 \text { June 1967) }\end{array}$ \\
\hline \begin{tabular}{l|} 
First university \\
courses to \\
train science \\
communicators.
\end{tabular} & $\begin{array}{l}\text { MSc in science } \\
\text { communication at } \\
\text { Imperial College under } \\
\text { John Durant }\end{array}$ & $\begin{array}{l}\text { 1990/91 } \\
\text { academic } \\
\text { year }\end{array}$ & $\begin{array}{l}\text { 1989-90: Undergraduate } \\
\text { BSc module in science } \\
\text { communication at University } \\
\text { College London by Steve Miller }\end{array}$ \\
\hline $\begin{array}{l}\text { First master's } \\
\text { students } \\
\text { in science } \\
\text { communication } \\
\text { graduate. } \\
\end{array}$ & $\begin{array}{l}\text { Graduates from the } \\
\text { Imperial College } \\
\text { MSc in Science } \\
\text { Communication }\end{array}$ & 1993 & \\
\hline $\begin{array}{l}\text { First PhD } \\
\text { students } \\
\text { in science } \\
\text { communication } \\
\text { graduate. }\end{array}$ & $\begin{array}{l}\text { Jane Gregory, } \\
\text { University of London }\end{array}$ & 1998 & $\begin{array}{l}\text { Thesis title 'Fred Hoyle and the } \\
\text { popularisation of cosmology' }\end{array}$ \\
\hline $\begin{array}{l}\text { First national } \\
\text { conference } \\
\text { in science } \\
\text { communication. }\end{array}$ & $\begin{array}{l}\text { BAAS 'Science and } \\
\text { the Citizen' conference } \\
\text { (mainly for science } \\
\text { enthusiasts) }\end{array}$ & 1943 & $\begin{array}{l}\text { 1990: 'Politics and Publics } \\
\text { for Science and Technology' } \\
\text { conference organised by the } \\
\text { Science Museum and EASST. } \\
\text { Mainly for academics. } \\
\text { 1993: 'Building Bridges' } \\
\text { conference organised by BAAS. } \\
\text { 2002: First national 'Science } \\
\text { Communication' conference } \\
\text { organised by BAAS/BSA. } \\
\text { 2013: First national 'Engage' } \\
\text { conference organised by } \\
\text { the NCCPE }\end{array}$ \\
\hline
\end{tabular}




\begin{tabular}{|c|c|c|c|}
\hline Event & Name & Date & Comment \\
\hline \begin{tabular}{|l|} 
National \\
government \\
program to \\
support science \\
communication \\
established. \\
\end{tabular} & $\begin{array}{l}\text { The Committee on the } \\
\text { Public Understanding } \\
\text { of Science (COPUS), } \\
\text { instituted its first } \\
\text { funding scheme }\end{array}$ & 1986 & $\begin{array}{l}\text { COPUS had representatives } \\
\text { from the Royal Society, the } \\
\text { BSA and the Royal Institution. } \\
\text { Funded by UK Government's } \\
\text { Office of Science and } \\
\text { Technology }\end{array}$ \\
\hline \begin{tabular}{|l|} 
First significant \\
initiative or report \\
on science \\
communication.
\end{tabular} & $\begin{array}{l}\text { Report of the Royal } \\
\text { Society on 'The Public } \\
\text { Understanding of } \\
\text { Science' led to the } \\
\text { setting up of COPUS } \\
\text { and the foundation of } \\
\text { university SciComm } \\
\text { courses }\end{array}$ & 1985 & $\begin{array}{l}\text { 1993: The first government } \\
\text { report in this area was 'Realising } \\
\text { our potential', which put a duty } \\
\text { on government-funded research } \\
\text { councils to communicate } \\
\text { science }\end{array}$ \\
\hline $\begin{array}{l}\text { National Science } \\
\text { Week founded. }\end{array}$ & $\begin{array}{l}\text { The UK 'Week of } \\
\text { Science' launched }\end{array}$ & 1994 & $\begin{array}{l}\text { Parallel to the European Week } \\
\text { of Science and Technology but } \\
\text { held at different time of year }\end{array}$ \\
\hline $\begin{array}{l}\text { A journal } \\
\text { completely or } \\
\text { substantially } \\
\text { devoted } \\
\text { to science } \\
\text { communication } \\
\text { established. }\end{array}$ & $\begin{array}{l}\text { Public Understanding } \\
\text { of Science founded } \\
\text { as a peer-reviewed } \\
\text { SciComm research } \\
\text { journal }\end{array}$ & 1992 & $\begin{array}{l}\text { Founded by the Science } \\
\text { Museum (published by the } \\
\text { Institute of Physics) }\end{array}$ \\
\hline $\begin{array}{l}\text { First significant } \\
\text { radio programs } \\
\text { on science. } \\
\end{array}$ & $\begin{array}{l}\text { The Stream of Life } \\
\text { on the BBC by Julian } \\
\text { Huxley }\end{array}$ & 1925 & $\begin{array}{l}\text { 1942: BBC Home Service Man's } \\
\text { Place in Nature }\end{array}$ \\
\hline \begin{tabular}{|l|} 
First significant \\
TV programs on \\
science.
\end{tabular} & $\begin{array}{l}\text { BBC TV Science } \\
\text { Review }\end{array}$ & 1952 & $\begin{array}{l}\text { 1954: Zoo Quest } \\
\text { 1957: The Sky at Night } \\
\text { 1964: First edition of BBC's } \\
\text { flagship science TV program } \\
\text { Horizon }\end{array}$ \\
\hline \begin{tabular}{|l|} 
First awards \\
for scientists \\
or journalists \\
or others \\
for science \\
communication. \\
\end{tabular} & $\begin{array}{l}\text { Royal Society Faraday } \\
\text { Award to Charles Taylor }\end{array}$ & 1986 & $\begin{array}{l}\text { 1998: Susan Greenfield first } \\
\text { woman to win Faraday Award. } \\
\text { 2005: Royal Society Kohn } \\
\text { Award for early-career scientists } \\
\text { for public engagement given to } \\
\text { Colin Pulham }\end{array}$ \\
\hline $\begin{array}{l}\text { Date hosted } \\
\text { a PCST } \\
\text { conference. } \\
\end{array}$ & PCST-16, Aberdeen & 2020 & $\begin{array}{l}\text { Postponed to } 2021 \text { because of } \\
\text { COVID-19 }\end{array}$ \\
\hline \multirow[t]{3}{*}{$\begin{array}{l}\text { Other significant } \\
\text { events. }\end{array}$} & & 1066 & $\begin{array}{l}\text { Bayeux Tapestry includes the } \\
1066 \text { passage of Halley's comet } \\
\text { in its woven narrative }\end{array}$ \\
\hline & & 1802 & $\begin{array}{l}\text { Evening public lectures } \\
\text { established at The Royal } \\
\text { Institution (founded in 1799) }\end{array}$ \\
\hline & & 1993 & $\begin{array}{l}\text { London 'Public Understanding } \\
\text { of Science' seminar series } \\
\text { established }\end{array}$ \\
\hline
\end{tabular}




\begin{tabular}{|l|l|l|l|}
\hline Event & Name & Date & Comment \\
\hline & 1994 & $\begin{array}{l}\text { First UK consensus conference } \\
\text { on 'Plant Biotechnology' held at } \\
\text { the Science Museum }\end{array}$ \\
\cline { 2 - 4 } & 2008 & $\begin{array}{l}\text { Six regional 'Beacons of Public } \\
\text { Engagement' plus a National } \\
\text { Coordination Centre set up }\end{array}$ \\
\cline { 2 - 4 } & 2014 & $\begin{array}{l}\text { UK Research Excellence } \\
\text { Framework includes 'Impact } \\
\text { Statements' so universities } \\
\text { explicitly receive funding for } \\
\text { science communication efforts }\end{array}$ \\
\hline
\end{tabular}

\section{Contributors}

Dr Melanie Smallman is lecturer in science and technology studies and co-director of the Responsible Research and Innovation Hub at University College London's Department of Science and Technology Studies.

Dr Simon J. Lock is associate professor in science communication and governance in the Department of Science and Technology Studies, University College London.

Steve Miller is Emeritus Professor of Science Communication and Planetary Science at University College London. 
This text is taken from Communicating Science: A Global Perspective, edited by Toss Gascoigne, Bernard Schiele, Joan Leach, Michelle Riedlinger, Bruce V. Lewenstein, Luisa Massarani and Peter Broks, published 2020 by ANU Press, The Australian National University, Canberra, Australia.

doi.org/10.22459/CS.2020.39 